\title{
101 創造力を育成するための体系的な発想法教育
}

Systematic Training Methods of Idea Conception for Creativity Education

正塚本 真也 (岡山大)

Sinya Tsukamoto

Faculty of Engineering, Okayama University, 3-1-1 Tsushima-naka, Kitaku, Okayama 700-8530 Japan

Key Words: Creativity Education, Systematic Training Methods, Idea Conception

\section{1. 精 哃}

岡山大学工学部では学生の創造力育成を目的とした発想 法教育を 2000 年から開始し，图1に示すように，現在では 学部 4 年間と大学院 2 年間の 6 年一貫の創造力訓練を体系的 に展開している。

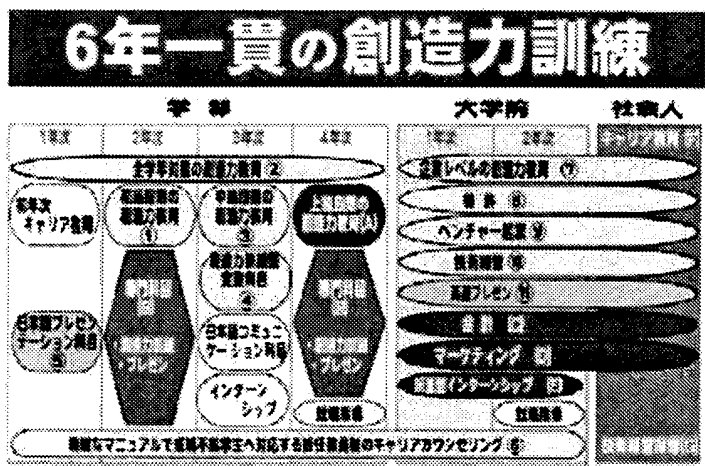

Fig. 1 Consistent training of creativity

(图 1 学部から大学院までの 6 年一貫の創造力訓練)

図示の大学院科目「企業レベルの創造力教育(7)」=授業名 「高度創成デザイン」では企業技術者に要求される創造力を 徹底的に訓練しており，最近その教育成果が現れ始めた。す なわち，授業で優秀なレポートを作成した大学院生に日本経 済新聞社主催の発想コンテスト「テクノルネサンスジャパ ン」へ応募させたところ，图 2 に示すように， 2 年連続で 5 〜 8名が受賞するという極めて顕著な教育成果が達成でき たのである。

本報告では，創造力を顕著に向上させるための体系的な発 想法教育について紹介する。

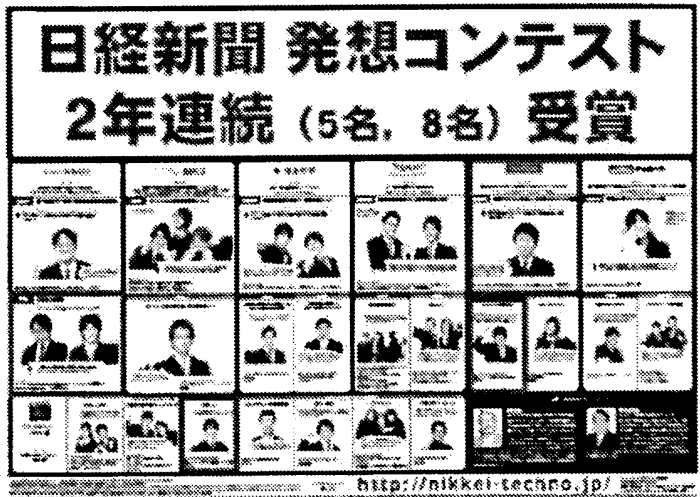

Fig.2 Remarkable effects of creativity training (图 2 創造力訓練の顕著な教育成果)

\section{2. 発想法教育の体系化}

発想法教育の開始初年は，担当教員の経験不足のため，学 生の創造力訓練は大失敗に終わった。この大失敗の原因分析 と教育法の研究開発によって，图 3 の体系的な発想法教育を 本学では構築した。

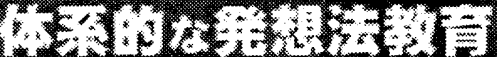

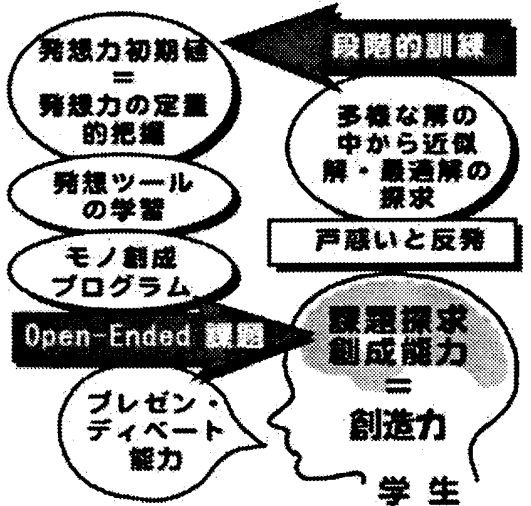

Fig.3 Systematic training methods of idea conception （图 3 体系的な発想法教育）

本教育法では，図示のように学生の発想力初期值を計測す ることで, 学習へのモチベーションを維持向上させている点 が特色の第 1 といえよう. 第 2 の特色は，発想力初期值の計 測で判明した発想力の乏しい学生に対して発想ツールを習 得させ，発想への具体的なサポートを実行している点である。 しかし，なんと言っても最重要なのは，担当教員が的確な Open-Ended 課題を考案し,これに基づいて学生の創造力を徹 底的に訓練していることだ。

因 4 は，本学の体系的な発想法教育を別の切り口から提示

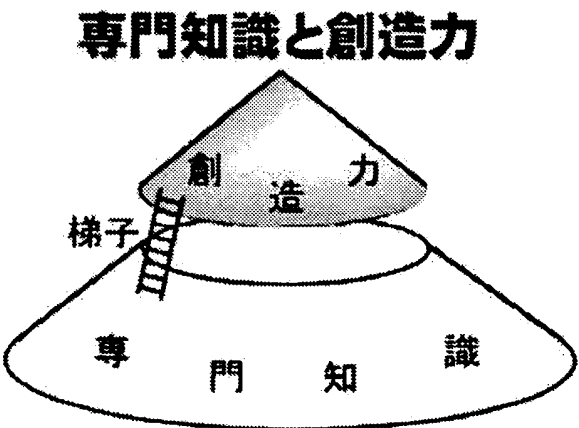

Fig.4 Method to demonstrate creativity

(图4 創造力を発揮するための方法) 


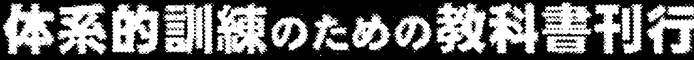

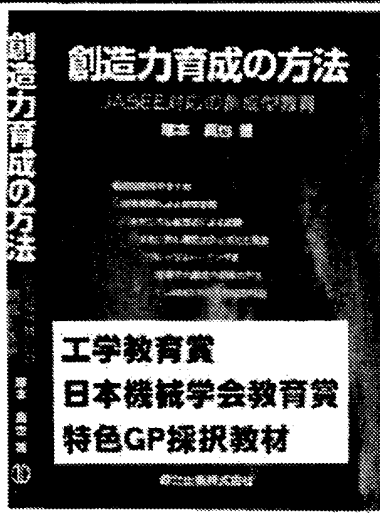

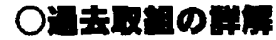
O整成量の焦大成 Ontwhines atann ○メカニカル発想法 OPBL

\section{Oフレーンストーミング

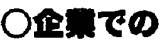

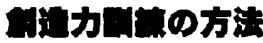

Fig.5 Texbook for systematic training of creativity

（图 5 体系的な創造力訓練のための教科書）

したものである. 従来までの大学高専教育では, 専門知識を いかに効率良く大量に習得させるかに注力してきて, 企業技 術者に不可欠な創造力訓練が実施されてこなかったことは 首肯せざるを得ないだろう。

それに対し，本教育法では図示の「梯子」を学生が自分で 組み立てて, 創造力の頂へ容易に到達し, 新規で独創的なア イデアが発揮できるように徹底的な訓練を実施している.

图 5 に，発想法教育のために執筆刊行した教科書（塚本真 也著 : 創造力育成の方法，森北出版）を示す.

本書では，学部段階の「発想ツール（メカ二カル発想法と ブレーンストーミング法) 訓練」から，大学院レベルにおけ る「企業での創造力訓練の方法」までの体系的な指導法がま とめられている.

ところで, 本学の発想法教育で学生の能力アップに大きく 寄与したのが, 图6の振り返りシートである. 本シートでは, 3つの取り組み課題ごとに学生の達成度評価を定量的に実 施し，その評価結果と教員の助言を付して，学生との間で往 復させ，さらに学生にも教員評価へ対しコメントと努力目標 を書かせることで，学習へのモチベーション向上と本教育に よる創造力育成のスパイラルアップが顕著に図られた.

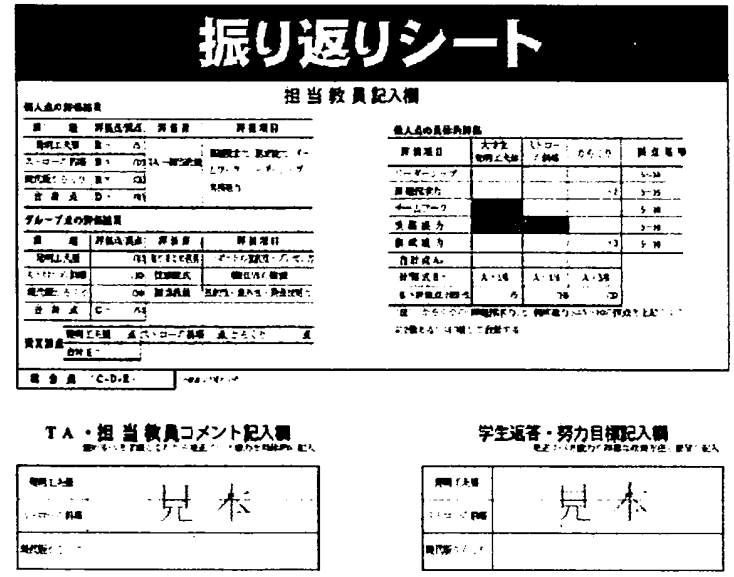

Fig.6 Achievement sheet of training

(圈6 振り返りシート)

\section{3. 発想法教育の晍著な教育効果}

图 7 に，本学における創造力訓練法の教育効果の一例を示 す．前述のように，本教育の開始 1 年目では発想法教育をほ とんど教授しない状態で 0pen-Ended 課題の「跳ねる機械」 に取り組ませた結果，「発想の広がり」という観点から判断 した学生の達成度は極めて低かった．ところが， 2 年目と 3 年目の受講学生へは，図 5 の教科書を用いて，体系的な創造 力訓練を実施することで，顕著な教育効果が現れてきた．

すなわち, これは図 6 の本学の振り返りシートによる達成 度の定量的評価法で学生のモチベーションを向上させなが ら，図 3 の体系的教育法で創造力を徹底訓練することで，極 めて高い教育効果が得られたことの証左である。ささらに，大 学院までの 6 年一貫教育を実施することで, 日本経済新聞社 主催の発想コンテスト「テクノルネサンスジャパン」におけ る 2 年連続受賞という快挙も達成できたのだ.

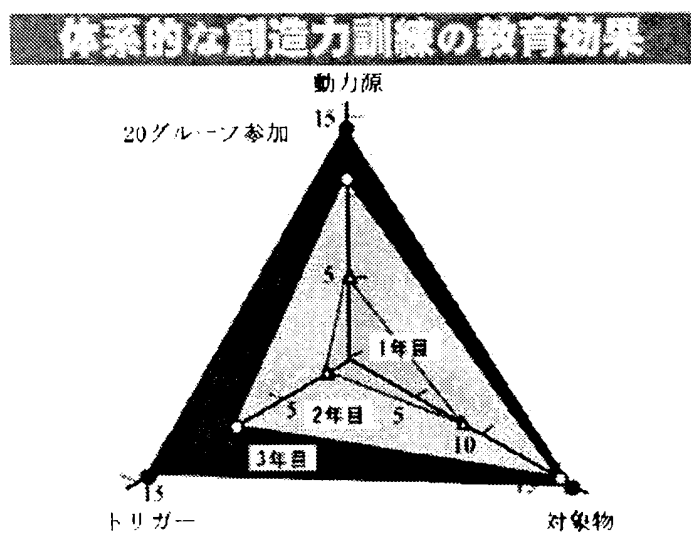

Fig.7 Educational effect example of creativity training

（园7 創造力訓練の教育効果の一例）

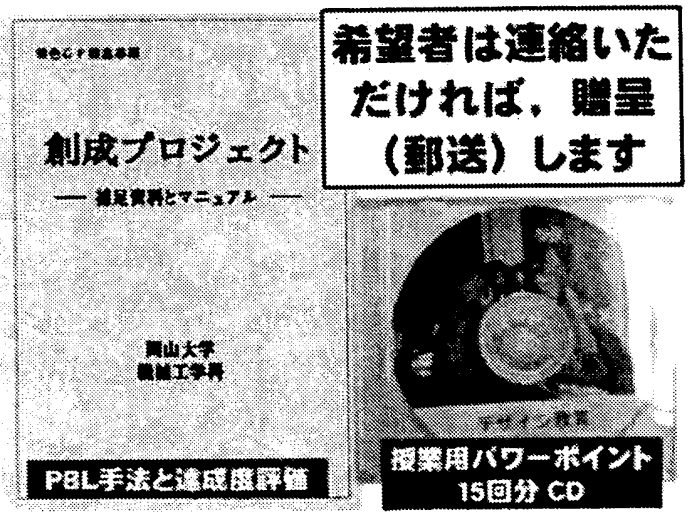

Fig.8 Presented free materials of systematic training （图8 体系的発想法に関する教育資料の贈呈）

图 8 は，振り返りシートと達成度の定量的評価法を解説し ている指導マニュアルならびに全 15 回分の授業用パワー ポイントCDである。

希望者は下記のメールアドレスへご連絡いただければ，贈 呈いたします。なお，本資料の著作権は全て開放しておりま すのでここ自由に使用いただけます。

tukamoto@mech.okayama-u.ac.jp 